\title{
Perancangan Aplikasi Proof Design Dan Proof Product Berbasis Desktop Menggunakan Devexpress
}

\author{
Bernadeta Silvia $^{1}$, Eko Sediyono ${ }^{2}$ \\ ${ }^{1,2}$ Universitas Kristen Satya Wacana Salatiga ${ }^{1,2}$ Fakultas Teknologi Informasi \\ 1672017247@student.uksw.edu, 2eko@uksw.edu
}

\begin{abstract}
Abstrak
PT. PB adalah perusahaan yang memproduksi smart card. Devisi marketing dan QC melakukan koordinasi secara manual saat menentukan design yang akan digunakan dalam smart card. Oleh karena itu diperlukan aplikasi untuk mempermudahkan koordinasi tersebut. Aplikasi ini bertujuan untuk mempermudahkan dalam menentukan design dan produk yang akan diproduksi. Pada penelitian ini disusun menggunakan metode $R \& D$. Aplikasi proof design dan proof product ini disusun berbasis desktop. Pada pembangunan aplikasi ini menggunakan bahasa C\# dengan menggunakan devexpress dan database yang digunakan adalah oracle. Penelitian ini bertujuan untuk mempermudahkan tim marketing (CS) dan QC (PIC) dalam koordinasi mengenai design yang akan digunakan dalam smart card yang akan diproduksi. Pengujian sistem yang digunakan dalam menguji aplikasi menggunakan pengujian blackbox. Pengisian kuisioner dilakukan untuk mengetahui kepuasan user terhadap aplikasi yang akan digunakan. Hasil dari penelitian ini adalah aplikasi proof design dan proof product berjalan sesuai fungsinya dan dapat membantu CS dan PIC dalam menyelesaikan tugasnya.
\end{abstract}

Kata kunci- design, desktop, devexpress, oracle.

\begin{abstract}
$P T . P B$ is a company that produces smart cards. The marketing and $Q C$ divisions coordinate manually when determining the design to be used in smart cards. Therefore, an application is needed to facilitate such coordination. This application aims to make it easier to determine the design and products to be produced. This study was compiled using R\&D method. Proof design application and proof product is compiled based on desktop. In the development of this application using the C\# language by using devexpress and the database used is oracle. This research aims to facilitate the marketing team (CS) and $Q C(P I C)$ in coordinating the design that will be used in the smart card to be produced. System testing used in testing applications using blackbox testing. Questionnaire filling is done to know the user's satisfaction with the application to be used. The result of this research is that the application of proof design and product evidence runs according to its function and can help CS and PIC to complete their tasks.
\end{abstract}

Keywords - Design; desktop; devexpress; oracle

\section{PENDAHULUAN}

Pada masa sekarang ini kemajuan dibidang teknologi mengalami perkembangan yang sangat pesat. Dalam berbagai bidang teknologi diciptakan dan dikembangkan untuk mempermudah dalam menyelesaikan pekerjaan. Manusia saat ini ingin segala kegiatan dilakukan secara cepat dan praktis, mulai dari kegiatan yang rumit seperti kegiatan bekerja dalam perusahaan sampai hal yang praktis seperti memesan makanan. Termasuk dalam sebuah 
perusahaan, sekarang sudah menggunakan teknologi untuk membantu dalam pekerjaan karyawannya. Karena perkembangan teknologi yang semakin maju dan keinginan pasar yang bervariasi maka bermunculan produk yang lebih inovatif. Produk tersebut memiliki desain unik yang dapat memikat konsumen.

Kerjasama antara divisi marketing dan QC sangat berpengaruh dalam produksi smart card di PT PB. Namun sekarang belum adanya aplikasi yang mewadahi untuk memudahkan dalam komunikasi dan memberi bukti desain dan produk yang akan diproduksi oleh PT. PB. Pengajuan desain masih dilakukan secara manual dengan mencetak desain dalam sebuah kertas. Sebelum menentukan desain sebuah produk yang akan diproduksi, customer akan mengajukan beberapa desain yang kira-kira sesuai dengan produk mereka. Desain yang diajukan akan mengalami berbagai revisi setelah diterapkan dalam sebuah kartu. Jika mengalami beberapa kali revisi akan menggunakan waktu yang lama dan menambah biaya untuk pencetakan desain dan lebih banyak menghasilkan kertas-kertas hasil desain. Selain itu bukti desain yang didiskusikan menjadi tidak terstruktur. Kegiatan secara manual ini juga berlaku untuk produk fisik yang akan diproduksi.

Berdasarkan latar belakang diatas maka dibutuhkan sebuah aplikasi. Aplikasi proof design dan proof product yaitu aplikasi yang membantu divisi marketing dan divisi QC berkomunikasi. Aplikasi ini memberi gambaran serta bukti desain yang akan digunakan oleh sebuah produk. Selain itu aplikasi ini juga memberi bukti dan gambaran produk yang diproduksi. Aplikasi ini juga digunakan untuk melihat kualitas hasil produk seperti apa yang akan dipilih oleh customer untuk produk mereka, kualitas rendah, kualitas sedang atau kualitas tinggi.

Aplikasi proof design dan proof product akan digunakan oleh internal perusahaan, oleh karena itu aplikasi ini akan dibangun berbasis desktop menggunakan bahasa C\# dan .NET Framework. Database yang digunakan dalam aplikasi ini adalah oracle database.

Pada penelitian yang berjudul "Implementasi Aplikasi Desain Kita Berbasis Mobile Dalam Upaya Peningkatan Pendapatan Percetakan Indonesia" menjelaskan mengenai pembuatan aplikasi marketplace khusus untuk jasa percetakan. Dalam perancangan sistem ini menggunakan UML. Sistem ini dibangun dengan dua jenis sistem yaitu sistem aplikasi mobile dan sistem website. Aplikasi ini digunakan untuk proses pemesanan design baju sesuai dengan keinginan user/konsumen. Aplikasi desain kita bermitra dengan beberapa pencetakan di Indonesia yang sebelumnya masih melakukan penerimaan secara manual. Berdasarkan penelitian ini Aplikasi dan Website Desain Kita dapat meningkatkan income dan pendapatan percetakan di Indonesia [1].

Penelitian lainnya yang berjudul "Perancangan Aplikasi Marketplace Jasa Percetakan Berbasis Website" berisi mengenai perancangan sebuah sistem untuk masyarakat untuk memudahkan dalam mencari percetakan. Masyarakat dapat lebih mudah mencari percetakan secara efisien dan efektif serta dapat membandingkan harga antara beberapa percetakan. Sistem ini dibangun dengan metode waterfall, dengan bahasa pemrograman PHP dan menggunakan database MySQL [2].

Pada penelitian lain yang berjudul "Sistem Informasi Produksi Pakaian berbasis Desktop". Penelitian ini bertujuan untuk membuat kegiatan produksi, manajemen pembelian dan persediaan perusahaan menjadi lebih mudah. Sistem ini dianalisa dan dirancang menggunakan metode Waterfall. Sistem ini berbasis desktop dan pengujian sistem dilakukan dengan menggunakan metode BlackBox. [3]

Pada penelitian yang lain berjudul "Sistem Informasi Jasa Pemesanan Percetakan Berbasis Android" bertujuan untuk merancang sebuah sistem informasi yang berupa jasa pemesanan percetakan berbasis android. Penelitian ini dilakukan pada Percetakan Mufida Digital Printing Kota Gorontalo. Tujuan penelitian ini adalah pelanggan dalam melakukan pemesanan percetakan menjadi lebih mudah. Dalam perancangannya aplikasi jasa pemesanan 
percetakan ini menggunakan UML dan diimplementasikan menggunakan Android Studio, MySQL dan PHP dengan metode penelitian yaitu penelitian deskriptif. [4]

Berdasarkan beberapa penelitian sebelumnya, memiliki konsep yang serupa dengan aplikasi Proof Design dan Proof Product. Pada penelitian sebelumnya membangun aplikasi berbasis web dan android, pada penelitian ini penulis membangun aplikasi berbasis desktop. Pada penelitian sebelumnya menggunakan database MySQL penelitian ini penulis menggunakan database Oracle disesuaikan dengan database yang sering digunakan oleh perusahaan.

Smart card sering disebut sebagai integrated circuit (IC) card atau chip card. Chip card sendiri dapat didefinisikan sebagai kategori umum yang didalamnya sudah mencangkup memory card dan smart card. Smart card juga dapat diartikan sebagai kartu plastik yang didalamnya mengandung memory chip dan microprocessor. Kartu ini dapat mengelola informasi yang terkandung dengan menambah dan menghapus. Salah satu keunggulan dari smart card adalah database yang ada di server tidak perlu diakses karena database tersebut sudah ada sebagian yang tersimpan didalam kartu. Sedangkan didalam memory card terdapat memory silicon tanpa microprocessor. Smart card memiliki fungsi dasar salah satunya untuk mengidentifikasi card holder ke sistem komputer. Card Holder di sini adalah pemilik asli kartu tersebut. Identifikasi ini diantaranya adalah otentifikasi organisasi yang telah membuat kartu dan cardholder serta hak aksesnya [5].

Secara umum desain dapat diartikan menjadi sebuah rancangan, gagasan atau sebuah rencana. Kamus Besar Bahasa Indonesia menyebutkan bahwa desain merupakan 1. Kerangka, bentuk, rancangan, 2. Motif pola, corak. Desain dapat diartikan pula sebagai sekumpulan konsep dan alat yang membantu untuk terciptanya sebuah produk. Desain dapat diartikan sebagai terjemahan fisik mengenai aspek ekonomi, sosial dan tata hidup manusia, juga merupakan cerminan budaya zamannya pengertian ini dikemukakan oleh Sachari dan Sunarya (2001). Desain adalah manifestasi kebudayaan yang dapat dilihat wujudnya. Desain merupakan produk dari nilai-nilai yang memiliki kurun waktu tertentu dalam masa berlakunya. Design memiliki pengertian lain yaitu suatu proses kreatif dalam menyelesaikan suatu masalah dalam hal yang berkaitan dengan perancangan suatu objek yang memiliki sifat fungsional atau estetis. Prinsip design diantaranya aspek teknis, material, melihat fungsi tanpa melupakan unsur garis, warna, tekstur, bentuk-bentuk dan keseimbangan komposisi, Beta (2008). Desain merupakan proses untuk merancang sebuah ide gagasan/permasalahan sebuah benda cipta yang memiliki dasar aspek teknis, fungsi dan material [6].

Secara umum produk dapat diartikan sebagai sesuatu yang dibuat oleh perorangan atau sekelompok orang guna mendapat keuntungan melalui proses jual beli dalam transaksi. Dalam bukunya yang berjudul unsur-unsur inti pemasaran dan manajemen pemasaran $(2003,45) \mathrm{H}$ Djaslim Saladin SE mengemukakan produk terbagi dalam beberapa pengertian yaitu: Dalam arti sempit produk dapat diartikan sebagai sekumpulan sifat-sifat kimia dan fisik yang berwujud dan dikumpulkan didalam suatu bentuk serupa dan yang telah dikenal. Dalam arti luas produk dapat diartikan sebagai sekelompok sifat-sifat yang tidak berwujud dan berwujud yang didalamnya sudah tercakup harga, warna, kemasan, prestise pabrik, prestise pengecer dan pelayanan yang diberikan konsumen sebagai kepuasan yang ditawarkan terhadap keinginan dan kebutuhan konsumen [6].

\section{METODE PENELITIAN}

Pada penelitian ini penulis menggunakan metode penelitian Research and Development (R\&D). Metode ini menggunakan model prosedural yaitu model deskriptif yang menggambarkan alur prosedur yang harus diikuti untuk menciptakan sebuah media tertentu 
sesuai yang diharapkan. Alur prosedur pengembangan pada penelitian ini disesuaikan dengan teori dari Sugiyono (2010) yang dapat dilihat pada gambar 5 [7].

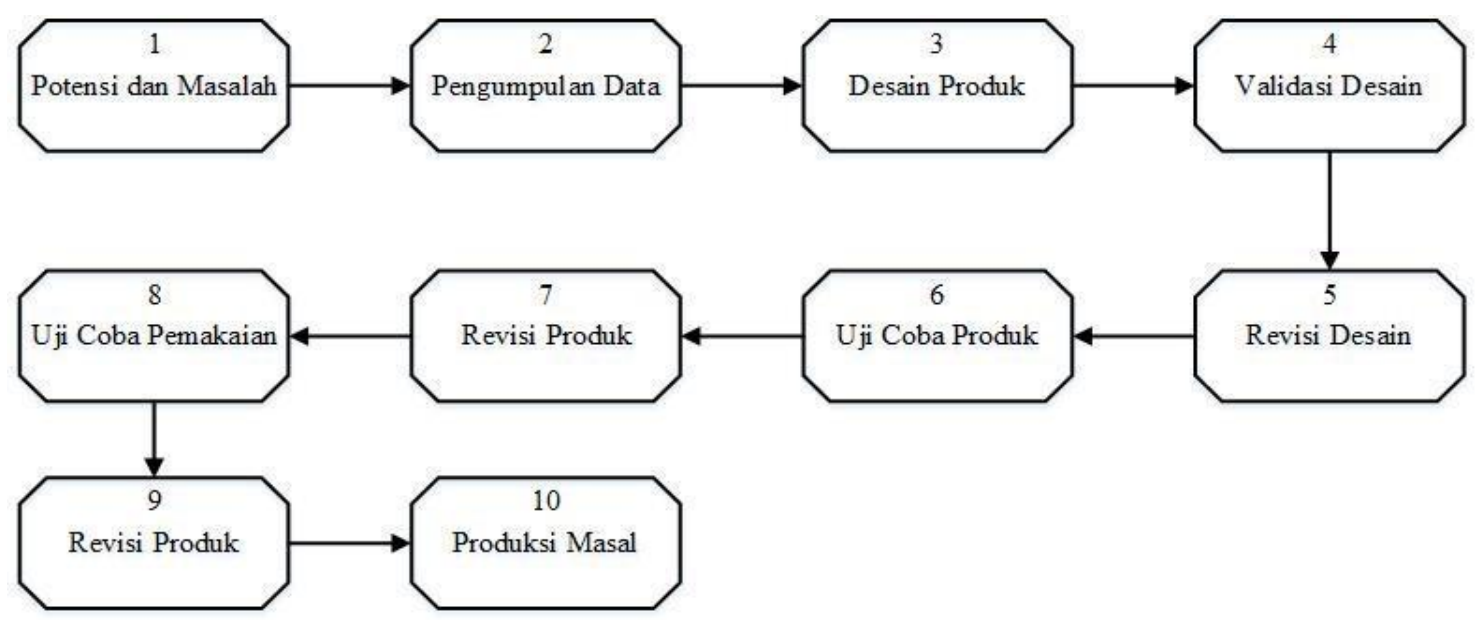

Gambar 1. Alur Prosedur R\&D

Berikut tahapan penjelasan masing-masing tahapan

a. Potensi dan Masalah

Metode penelitian R\&D memilihi tahapan pertama yaitu adanya potensi dan masalah. Penulis melakukan wawancara kepada salah satu karyawan di PT PB membahas mengenai sebuah sistem baru untuk mempermudah koordinasi antara bagian marketing dengan bagian QC (Quality Control) mengenai desain smart card yang akan diproduksi. Dari hasil pembahasan tersebut diperoleh sebuah potensi dan dapat diangkat menjadi sebuah masalah dalam penelitian. Pada penelitian ini digunakan untuk merancang sebuah sistem yang digunakan untuk QC dan Marketing dalam menentukan desain sebuah smart card yang akan diproduksi oleh PT PB. Sistem informasi ini akan dibangun berbasis desktop.

b. Pengumpulan Data

Selanjutnya di tahap ini penulis melakukan pencarian teori - teori yang bersumber dari jurnal, internet, buku serta melakukan wawancara dengan pengembang aplikasi yang ada di PT PB maupun pihak yang terkait dan penelitian sejenis guna mendukung penyelesaian masalah yang ada di dalam penelitian ini.

c. Desain Produk

Kemudian pada tahapan ini, setelah didapatkan hasil pada penelitian awal, penulis membuat perancangan menggunakan Unified Modeling Language (UML). Perancangan UML ini bertujuan untuk memodelkan kebutuhan sistem sehingga dapat mempermudah dalam pembanguan sistem. Pemodelan kebutuhan berupa use case diagram, flowchart, activity diagram, dan arsitektur sistem.

d. Validasi Desain

Pada tahap validasi desain ini, peneliti melakukan koordinasi dengan mentor penulis. Tujuannya untuk menilai perancangan sistem yang telah dibuat agar dapat digunakan secara rasional dan layak digunakan.

e. Revisi Desain

Setelah melakukan validasi desain tahapan selanjutnya adalah dilakukan penyesuaian jika terdapat kekurangan pada hasil validasi desain supaya aplikasi yang akan dibangun lebih sesuai dengan kebutuhan.

f. Uji Coba Produk

Pada tahap uji coba produk ini penulis melakukan pengujian awal dengan mencari kekurangan secara terbatas dan bug yang terdapat pada sistem. 
g. Revisi Produk

Pada tahap ini penulis melakukan revisi produk ketika terdapat kekurangan maupun bug berdasarkan pengujian awal.

h. Uji Coba Pemakaian

Uji coba pemakain akan dilakukan ketika aplikasi proof design dan proof product sudah jadi. Bertujuan untuk mengetahui kelayakan aplikasi yang telah dibangun. Pengujian dilakukan dengan menggunakan aplikasi secara umum agar terdeteksi ketika terdapat error saat digunakan, dan dapat dilakukan secara acak untuk memvalidasi performa dan fitur ketika aplikasi sedang berjalan.

i. Revisi Produk

Dilakukan peningkatan performa ketika menjumpai masalah yang dapat menghambat berjalannya sistem dan dilakukan perbaikan terhadap beberapa fitur yang error.

j. Produksi Massal

Produksi massal memiliki maksud sebagai implementasi dari sistem yang telah dibuat agar pihak yang terkait yaitu bagian Marketing dan bagian QC dapat menggunakannya. Sistem ini diharapkan dapat mempermudah dan membantu user dalam melakukan pekerjaannya.

\section{HASIL DAN PEMBAHASAN}

\section{Use Case Diagram}

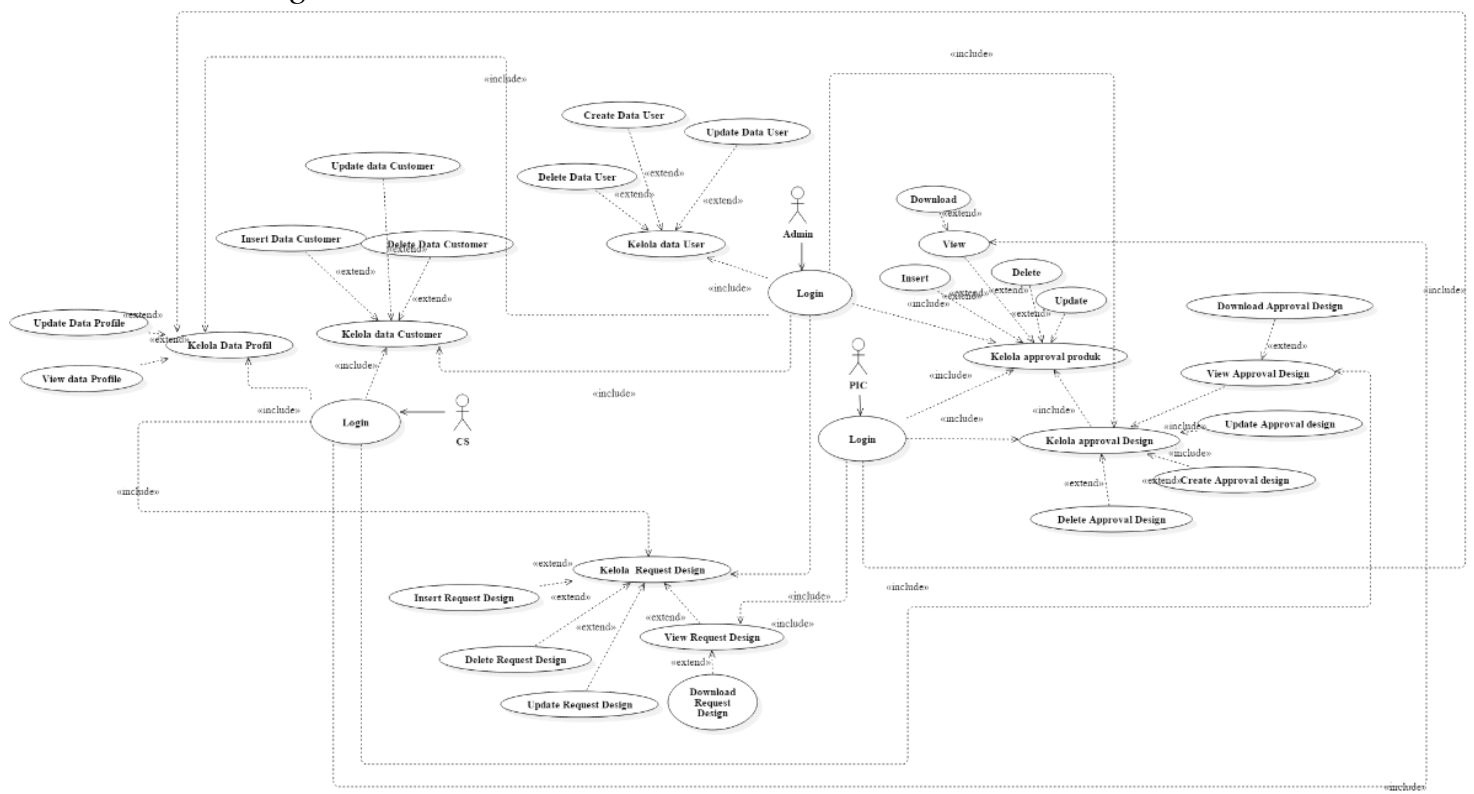

Gambar 2. Use Case Diagram

Use Case diagram merupakan pemodelan yang menggambarkan aplikasi yang akan dibuat. Fungsi-fungsi pada sistem akan dijelaskan pada use case diagram dengan sudut pandang user. Fungsi-fungsi yang ada pada use case dapat dibuat sebagai batasan-batasan untuk merancang suatu aplikasi sehingga aplikasi yang akan dibangun sesuai dengan permintaan client [8]. Use case aplikasi proof design dan proof produk dapat dilihat pada gambar 2.

Use case pada aplikasi proof design dan proof product memiliki tiga actor yaitu Admin yang dapat mengakses semua menu pada aplikasi. CS yang dapat mengelola data customer, request design, melakukan acc atau revisi design, request product, dan melakukan acc dan revisi 
product. PIC yang dapat mengelola approval product dan approval design dengan menambah, mengedit, melihat dan menghapus.

\section{Class Diagram}

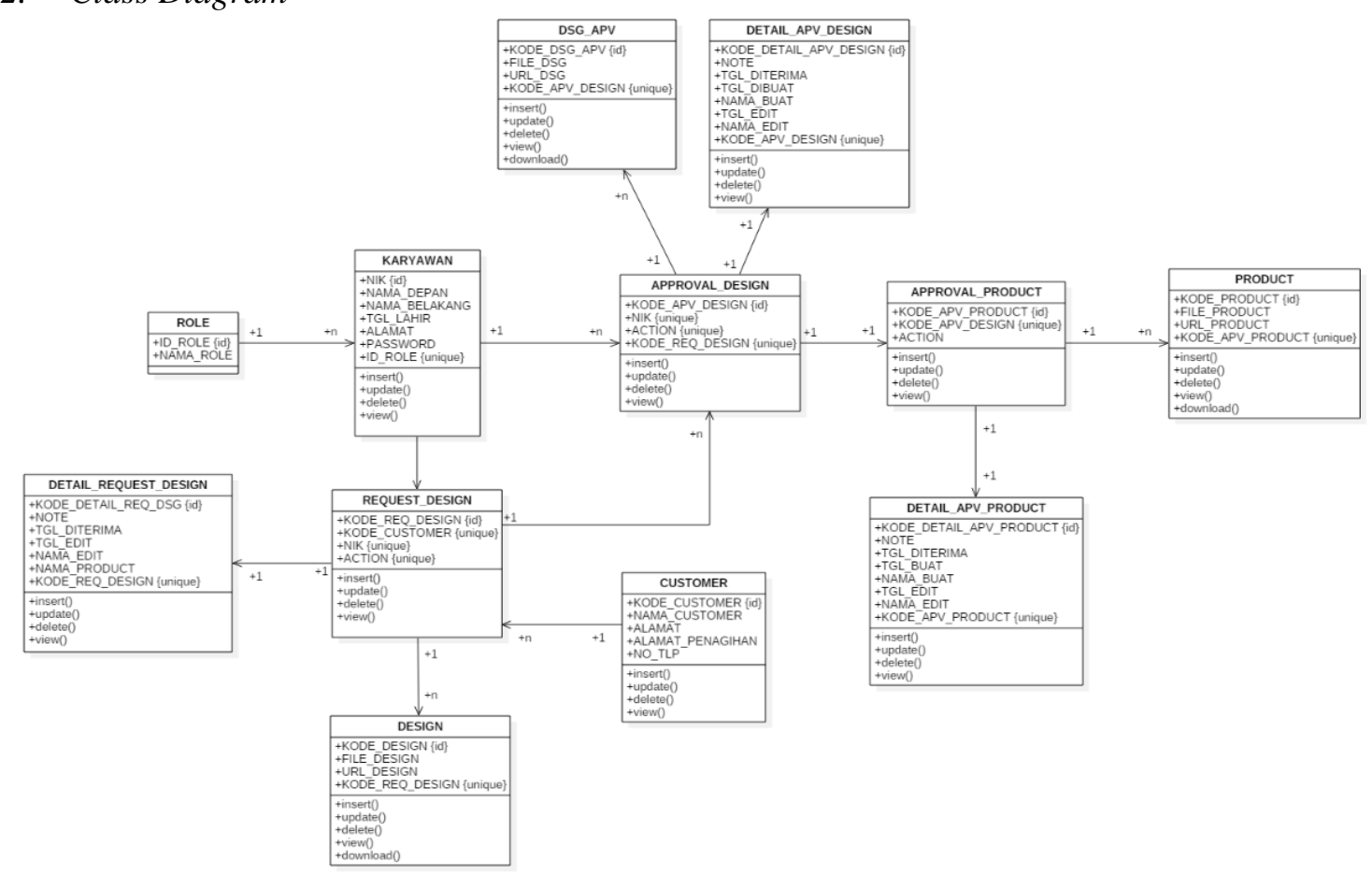

Gambar 3. Class Diagram

Class diagram adalah model yang menggambarkan hubungan antar class dan deskripsi serta struktur class. Didalam diagram ini juga menggambarkan atribut suatu sistem, dan metode dan fungsinya. Gambar class diagram dapat menunjukkan relasi antar class dan akses setiap class. [9]Class diagram pada aplikasi proof design dan proof product dapat dilihat pada gambar 3.

\section{Prototype}

Aplikasi proof design dan proof product dibangun menggunakan bahasa C\#. Pembuatan user interface dalam aplikasi ini sebagian besar menggunakan devexpress dan database yang digunakan adalah oracle. Mengkoneksikan dengan database oracle menggunakan Oracle. Managed Data Access.

Aplikasi proof design dan proof product dimulai ketika user melakukan login. Pada halaman ini terdapat inputan berupa username dan password. Login dilakukan dengan mengisi NIK (Nomor Induk Karyawan) sebagai username dan password oleh user yang sudah didaftarkan oleh admin sebelumnya lalu menekan tombol login. User yang dapat masuk ke dalam aplikasi adalah user yang telah didaftarkan terlebih dahulu oleh admin. User yang belum didaftarkan oleh admin tidak dapat melakukan login pada aplikasi. Antarmuka halaman login dapat dilihat pada gambar 4. 


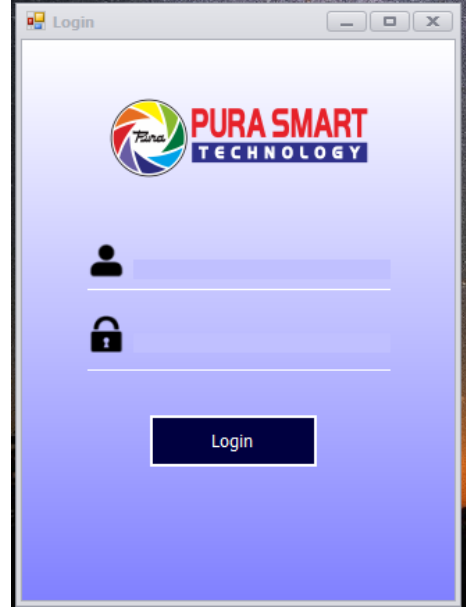

Gambar 4. Halaman Login

Username dan password yang telah diinput oleh user pada halaman login akan diperiksa dengan daftar data user yang ada di database. User akan masuk kedalam aplikasi jika memasukan username dan password yang sama dengan data pada database. User tidak dapat masuk jika username dan password tidak sesuai. Selain itu pada saat user melakukan login akan dilihat role dari user tersebut dan menentukan menu-menu yang dapat diakses.

Jika login yang dilakukan user berhasil akan masuk pada halaman Home. Pada halaman ini terdapat informasi mengenai user yang sedang login berupa NIK (Nomor Induk Karyawan) dan Rolenya. Terdapat empat menu yaitu home, design, dan Product. Home memiliki beberapa submenu yaitu home, profile, user dan customer. Menu design adalah menu untuk melakukan request design dan approval design. Ada beberapa submenu pada menu design ini antara lain request design, daftar design, design done, design acc dan design revisi. Pada menu Product terdapat empat sub menu yaitu product proces, product done, product acc, dan product revisi.

Submenu profile, pada submenu ini dapat diakses oleh semua user, baik admin, CS maupun PIC. Pada submenu ini berisi data user NIK, nama depan, nama belakang, alamat tanggal lahir dan password. User dapat memperbarui pada data dirinya, namun NIK dan role tidak dapat diubah oleh user itu sendiri namun, hanya dapat diubah oleh admin pada menu lain yaitu di menu user. User langsung dapat merubah pada bagian textbox yang tersedia, setelah selesai user dapat menekan tombol update yang berada di bawah sebelah kanan, dan data user menampilkan data user yang telah diubah.

Menu user, pada submenu ini hanya dapat diakses oleh admin. Pada menu ini admin dapat mengelola data user. Admin dapat menambah, memperbarui, dan menghapus data user. Pada menu ini dibuat menggunakan user control. Pada bagian inputan dibuat menggunakan textbox dari devexpress dan daftar user pada bagian bawah menggunakan devexpress gridcontrol.

Menu customer, submenu ini dapat diakses oleh admin dan CS. Menu ini digunakan untuk mengelola data customer. Mulai dari nama, alamat, alamat penagihan. Pada menu ini CS dapat melakukan update, insert dan delete data customer. Data customer ini nanti digunakan untuk melakukan request design.

Menu request design, yang memiliki akses pada menu design ini adalah CS dan admin. Pada menu ini CS dapat melakukan request design dengan mengisi form yang tersedia. Inputan nama customer dibuat menggunakan combobox untuk memudahkan dalam memilih customer yang telah terdaftar dalam aplikasi. Pada saat CS menginput request design, CS dapat menambahkan beberapa design mentah. Design mentah ini nantinya akan dibuat oleh PIC disesuaikan dengan card yang akan diproduksi. Antarmuka halaman request design dapat dilihat pada gambar 5 . 


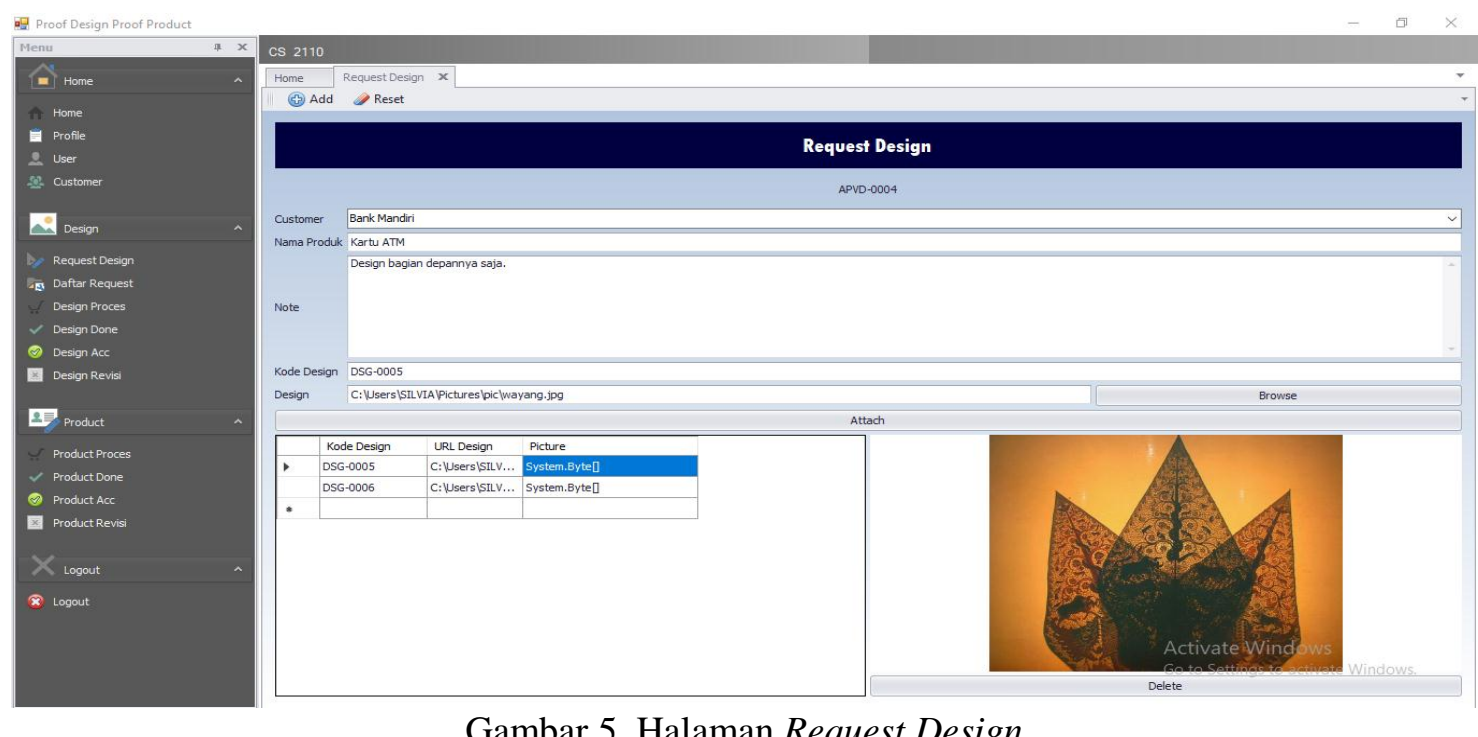

Gambar 5. Halaman Request Design

Daftar Design, pada menu ini dapat diakses oleh semua user namun dengan tujuan ynag berbeda. CS dapat mengakses halaman ini jika harus memperbarui atau menghapus request design yang salah di input. PIC dapat mengakses halaman ini untuk memilih request design yang akan diapproval. Saat melakukan approval design PIC dapat mengunduh design yang akan dibuat. Halaman ini merupakan tabel yang berisi daftar request design.

Menu design proces, pada menu ini CS dapat melihat request design yang telah diapproval dan yang melakunan approval design dari request design yang telah diinput. Pada menu ini berisi daftar design yang sedang dikerjakan oleh PIC. Selain itu pada menu ini PIC dapat melakukan insert design yang telah dibuat dengan menekan design yang ingin diinput lalu menekan insert. Setelah itu akan menuju halaman untuk insert design yang telah dibuat. Pada menu ini PIC dapat mengisi design yang telah dibuat pada form. Desain yang dapat diinput bisa lebih dari satu.

Setelah PIC melakukan insert design, cs dapat melihat desain dan menentukan design diacc atau direvisi. Design done, pada menu ini terdapat daftar desain yang telah selesai dikerjakan oleh PIC. Pada menu ini CS dapat melihat daftar masing-masing design dan melihat detail masing-masing design. Menu design acc berisi desain yang telah di acc oleh CS sedangkan menu design revisi berisi design yang berisi daftar desain yang harus direvisi oleh PIC.

Setelah CS melakukan acc atau revisi PIC dapat melihat hasilnya. Menu design revisi yang berisi daftar design yang harus direvisi. Menu design ACC yang berisi setail desain yang telah di acc dan halaman CS untuk melakukan request product. Pada menu revisi ini PIC dapat melihat bagian mana yang harus direvisi dan sekaligus dapat menambahkan desain baru yang telah di acc.

Ketika hasil design akan diproduksi CS dapat melihat daftar hasil desain yang di acc, selanjutnya dapat melakukan request product dari halaman detail acc design. Antarmuka halaman request product dapat dilihat pada gambar 6. 


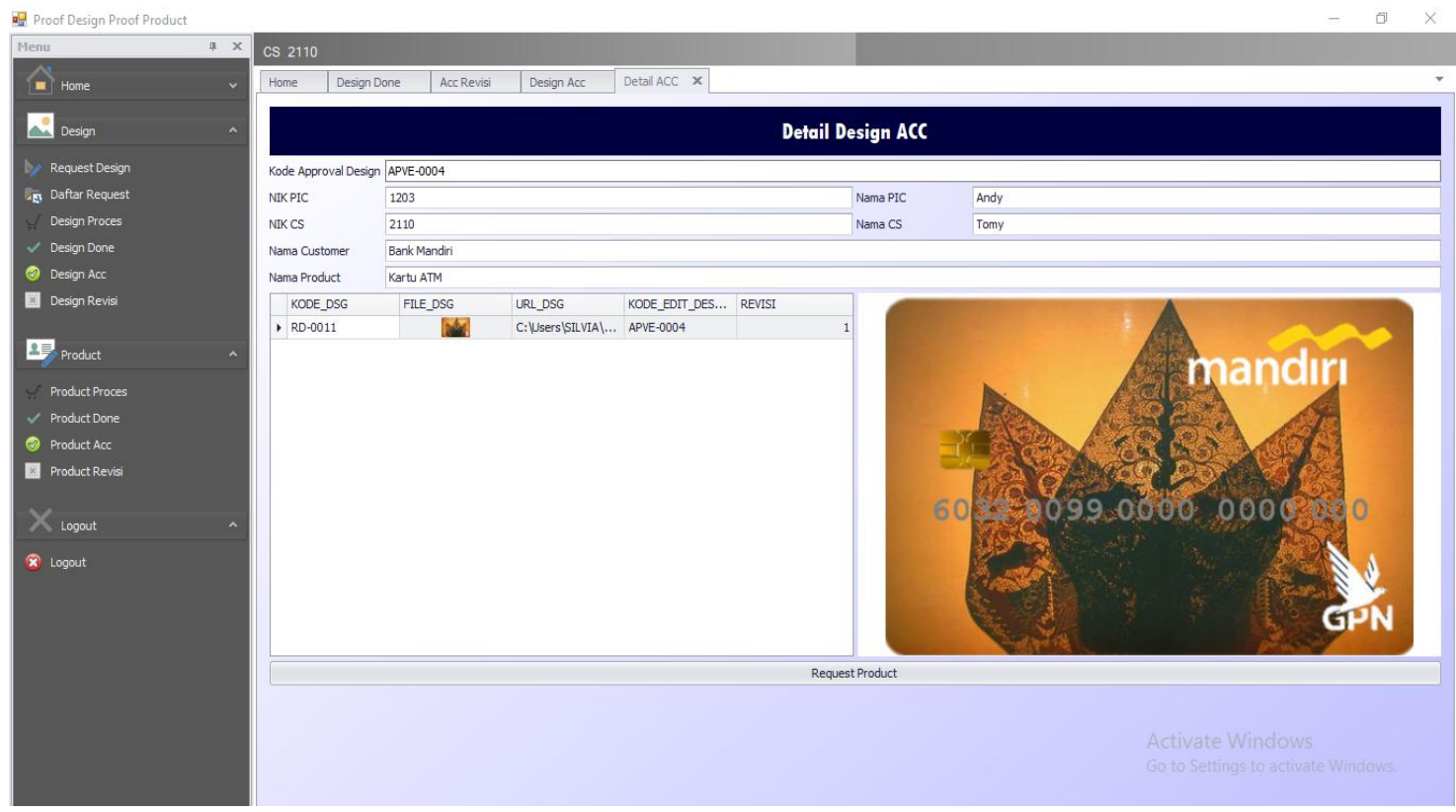

Gambar 6. Halaman Request Product

Setelah CS melakukan request product, product akan segera dicetak dalam tiga kualitas gambar kualitas tinggi, sedang dan rendah. PIC akan memasukkan gambaran ketiga kualitas dalam aplikasi pada menu product proses. Setelah itu CS dapat memilih kualitas yang dikehendaki customer dengan melakukan revisi product dan acc product pada menu product done. PIC dapat menambahkan hasil revisi pada menu product revisi. PIC dan CS dapat melihat hasil yang di acc pada menu product acc. Antarmuka halaman product yang telah di acc dapat dilihat pada gambar 7 .

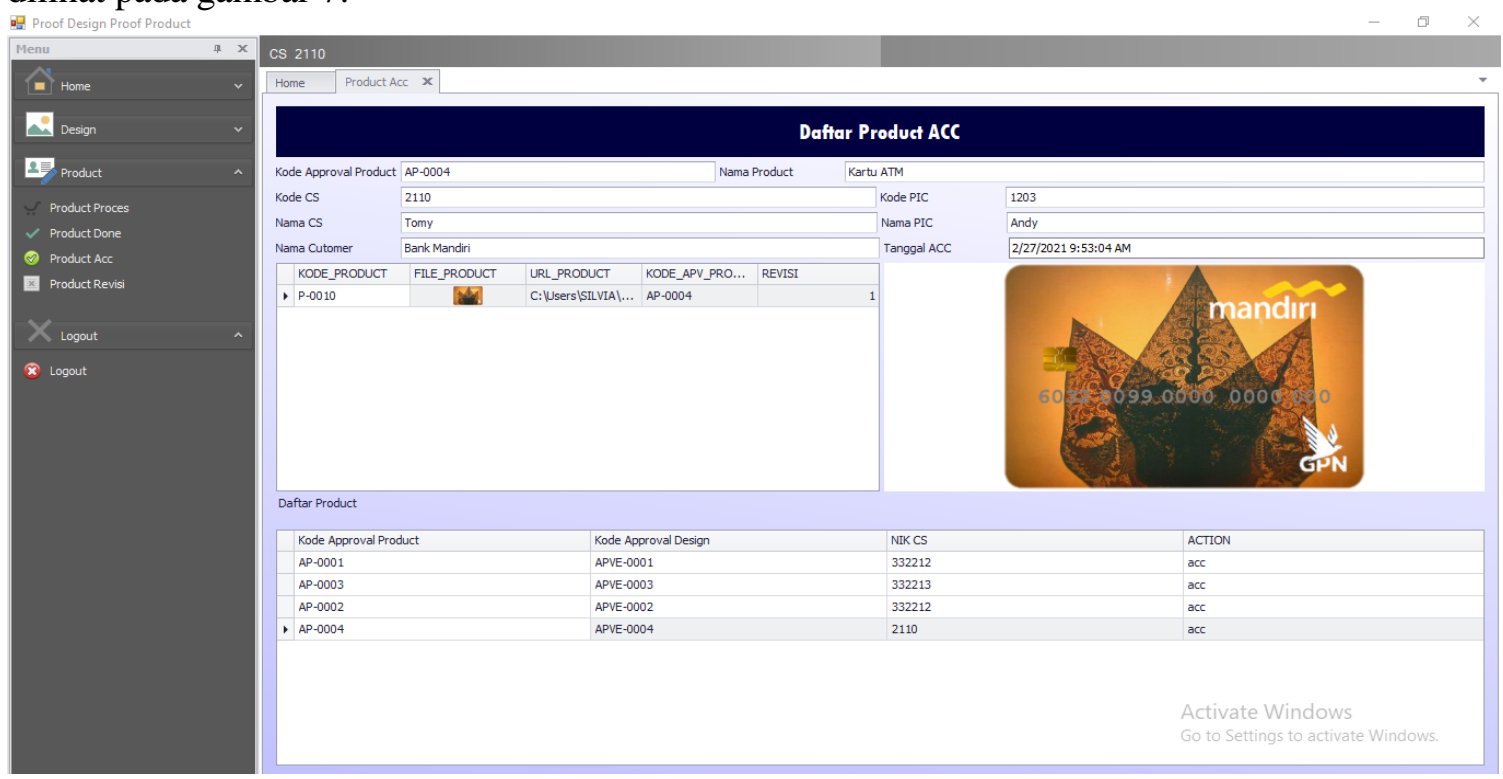

Gambar 7. Halaman Product ACC

Semua tahapan sudah dilakukan dari perancangan, penerapan metode dan hasil aplikasi, maka dilakukan pengujian sistem untuk mengetahui aplikasi proof design dan proof product dapat berjalan sesuai dengan fungsinya. Selanjutnya memberikan kuesioner kepada 5 karyawan. Berikut daftar pertanyaan yang terdapat pada kuesioner yang dibagikan: 
- Tampilan aplikasi proof design dan proof product sudah baik.

- Fungsi yang ada didalam aplikasi proof design dan proof product sudah sesuai.

- Kemudahan dalam pengoprasian aplikasi proof design dan proof product secara keseluruhan.

- Aplikasi proof design dan proof product nyaman digunakan.

- Aplikasi proof design dan proof product bersifat user friendly, user mudah untuk belajar menggunakan aplikasi.

- Aplikasi proof design dan proof product dapat dikembangkan lagi untuk memudahkan dalam koordinasi produksi smart card.

- Aplikasi proof design dan proof product memudahkan dalam menentukan design dan produk smart card yang akan diproduksi.

Skala penilaian yang dilakukan pada setiap pertanyaan yaitu 1-5.

$\begin{array}{ll}\text { Sangat setuju } & =5 \\ \text { Setuju } & =4 \\ \text { Cukup setuju } & =3 \\ \text { Tidak setuju } & =2 \\ \text { Sangat Tidak setuju } & =1\end{array}$

Hasil dari pengisian kuesioner oleh karyawan akan diubah kedalam bentuk skala Likert. Skala Likert merupakan skala yang digunakan guna mengukur pendapat atau persepsi seseorang atau kelompok, dalam penelitian ini yaitu aplikasi prof design dan proof product[10]. Penggunaan skala ini untuk menghitung persentase dari masing-masing pertanyaan. Berikut rumus persamaan skala Likert.

Indeks Kesesuaian Kasar $(\%)=($ Total Skor/Skor Maksimum $) \times 100 \%$

Tabel 1. Persentase Likert

\begin{tabular}{|c|c|c|c|c|c|c|c|}
\hline \multirow[t]{2}{*}{ Pertanyaan } & \multicolumn{5}{|c|}{ Skala Penilaian * Frekuensi Kemunculan Data } & \multirow[t]{2}{*}{$\begin{array}{l}\text { Total } \\
\text { Skor }\end{array}$} & \multirow[t]{2}{*}{$\operatorname{IKK}(\%)$} \\
\hline & 5 & 4 & 3 & 2 & 1 & & \\
\hline 1 & & 20 & & & & 20 & $80 \%$ \\
\hline 2 & & 20 & & & & 20 & $80 \%$ \\
\hline 3 & & 16 & 3 & & & 19 & $76 \%$ \\
\hline 4 & & 16 & 3 & & & 19 & $76 \%$ \\
\hline 5 & & 20 & & & & 20 & $80 \%$ \\
\hline 6 & 10 & 12 & & & & 22 & $88 \%$ \\
\hline 7 & & 16 & 3 & & & 19 & $76 \%$ \\
\hline \multicolumn{7}{|c|}{ Rata-rata } & $79,42 \%$ \\
\hline
\end{tabular}

Berdasarkan perhitungan persentase Skala Likert yang dapat dilihat pada tabel 2 aplikasi yang dibuat sudah baik. Kesimpulan ini didapat dari hasil perhitungan pada tabel 2 yang disesuaikan pada persentase kategori nilai skala likert[11] yang dapat dilihat pada tabel 3. Aplikasi sudah sesuai dengan keinginan user dan kebutuhan user, design tampilan dan fungsifungsi sudah sesuai.

Tabel 2. Persentase Kategori Nilai Skala Linkert

\begin{tabular}{|c|c|}
\hline$\%$ Kepuasan & Keterangan \\
\hline $0 \%-19.99 \%$ & Sangat Buruk \\
\hline $20 \%-39.99 \%$ & Kurang Baik \\
\hline $40 \%-59.99 \%$ & Cukup \\
\hline $60 \%-79.99 \%$ & Baik \\
\hline $80 \%-100 \%$ & Sangat Baik \\
\hline
\end{tabular}




\section{KESIMPULAN}

Berdasarkan penelitian yang telah dilakukan dapat disimpulkan bahwa aplikasi proof design dan proof product berjalan sesuai fungsinya. Aplikasi dapat membantu marketing untuk melakukan request design, merevisi atau meng acc product dan design serta melakukan request product. Membantu QC untuk melakukan approval design dan approval product. Kegiatan menentukan design dan product lebih cepat, terstruktur dan hasilnya dapat dilihat dengan lebih mudah dan jelas.

\section{SARAN}

Saran untuk pengembang selanjutnya untuk menambahkan bagian preorder, sehingga proses untuk produksi smart card dapat dilakukan pada satu aplikasi yang sama.

\section{UCAPAN TERIMA KASIH}

Penulis mengucapkan terima kasih kepada Universitas Kristen Satya Wacana Salatiga yang telah memberi dukungan terhadap penelitian ini.

\section{DAFTAR PUSTAKA}

[1] H. F. Harumy. 2018, "Implementasi Aplikasi Desain Kita Untuk Menambah Income dan Pendapatan Percetakan Indonesia," J. INFORMATICS Telecommun. Eng., Vol. 2, No. 1, p. 9, Jul. doi: 10.31289/jite.v2i1.1624.

[2] R. Fauzi, S. Wibowo, and D. Y. Putri. 2018, "Perancangan Aplikasi Marketplace Jasa Percetakan Berbasis Website,” Fountain Informatics J., Vol. 3, No. 1, pp. 2548-5113, doi: 10.21111/fij.v3i1.1824.

[3] K. D. Prasetyo, D. Sukma, and F. N. Khasanah. 2018, "Sistem Informasi Produksi Pakaian Berbasis Desktop," PIKSEL Penelit. Ilmu Komput. Sist. Embed. Log., Vol. 6, No. 2, pp. 139-148, Sep., doi: 10.33558/piksel.v6i2.1505.

[4] Z. Purnomo, J. Karim, B. Senung, and S. Abdussamad. 2020, "Sistem Informasi Jasa Pemesanan Percetakan Berbasis Android," Jambura J. Electr. Electron. Eng., Vol. 2, No. 2, pp. 44-51, Jul, doi: 10.37905/jjeee.v2i2.6006.

[5] S. A. Kadir and A. Muis. 2018, "Implementasi Kriptografi Kurva Eliptik pada Sistem Keamanan Smart Card," Semin. Nas. Has. Penelit. Pengabdi. Kpd. Masy., Vol. 0, No. 0, Dec. Accessed: Mar. 20, 2021. [Online]. Available: http://jurnal.poliupg.ac.id/index.php/snp2m/article/view/936.

[6] Rusdiono. 2019, “Desain Kemasan Produk Kekinian 'Mamayu Rice Box' Di Era Revolusi Industri 4.0," TEKINFO, Vol. 1, No. 2 Oktober, pp. 128 - 135-128 - 135, Accessed: Mar. 20, 2021. [Online]. Available: http://103.78.9.46/index.php/ti/article/view/367. 
[7] Prof. Dr. Sugiyono. 2010, Metode Penelitian Kuantitatif, Kualitatif, dan R\&D. Alfabeta, Bandung.

[8] T. Wiranda and M. Adri. 2019, "Rancang Bangun Aplikasi Modul Pembelajaran Teknologi WAN Berbasis Android," VoteTEKNIKA (Vocational Tek. Elektron. dan Inform., Vol. 7, No. 4, pp. 2302-3295, Accessed: Mar. 22, 2021. [Online]. Available: http://ejournal.unp.ac.id/index.php/voteknika/index.

[9] A. N. Rachman, C. M. S. Ramdani, and E. N. F. Dewi. 2020, "Implementasi Aplikasi Toko Online Ganger Untuk Pendaur Ulang Sampah Berbasis Web Di Tasikmalaya," doi: 10.20885/jattec.vol1.iss1.art2.

[10] H. Adang Sutedja. 2020, Pengantar Statistika, Widina Bhakti Persada, Bandung

[11] F. Okta Widarta, N. Muhammad, P. Studi Pendidikan Biologi PSDKU Unsyiah, G. Lues, P. Studi Pendidikan Biologi FKIP Unsyiah, and B. Aceh. 2020, "Persepsi Siswa Terhadap Keterampilan Dasar Mengajar Mahasiswa Prodi Pendidikan Biologi Psdku Unsyiah Gayo LUES,” Biot. J. Ilm. Biol. Teknol. dan Kependidikan, Vol. 8, No. 1, pp. 106-118, Jul. doi: 10.22373/biotik.v8i1.6557. 